\title{
Algajate ja kogenud õpetajate praktilise teadmise avaldumine tunnisündmuste kommenteerimisel stimuleeritud meenutuse meetodil
}

\author{
Anne Okas ${ }^{\mathrm{a} 1}$, Marieke van der Schaaf ${ }^{\mathrm{b}}$, Edgar Krull ${ }^{\mathrm{a}}$ \\ a Tartu Ülikooli haridusteaduste instituut \\ ${ }^{\mathrm{b}}$ Utrecht University, Department of Education
}

\begin{abstract}
Annotatsioon
Artiklis tutvustatav uurimus on osa mahukamast õpetaja professionaalset arengut käsitlevast uurimistööst, mille eesmärk on analüüsida algajate ja kogenud õpetajate praktilist teadmist tunnitöö korraldamisel. Viimastel aastakümnetel on õpetamistegevuse videolindistamist üha sagedamini kasutatud õpetajatöö uurimise meetodina. Õppetundide videolindistuste abil saab pärast tundi analüüsida, milline oli töökorraldus klassis, kuidas laabus koostöö õpetaja ja õpilaste vahel ehk milline oli õpetajapoolne juhendamine ning milline õpilaste tegevus tunnis. Tunnivideo võimaldab dokumenteerida tunnis toimunut ja on seeläbi abiks õpetaja professionaalse arengu toetamisel ning õpetamise kvaliteedi parandamisel.

Uuringus osales kümme algajat ja kümme kogenud õpetajat, kes panid kokku oma professionaalse arengu mapi - portfoolio, mille üks komponente on tunnivideo. Artikli aluseks oleva materjali kogumine hõlmas kaht etappi: valimisse arvatud õpetajate tundide videolindistamist ning õpetajapoolset tundide kommenteerimist stimuleeritud meenutuse meetodil. Õpetamistegevuse käsitlemise teoreetiliseks lähtekohaks käesolevas uurimuses on õpetaja praktilise teadmise kontseptsioon.

Kvalitatiivse sisuanalüüsi tulemused näitavad, et kogenud õpetajate kommentaarides ilmnev praktiline teadmine on terviklikum ning see käsitleb õpetamist kui õppija arendamist. Algajad õpetajad, tundes küll teooriat, keskenduvad eelkõige oma aine õpetamisele.
\end{abstract}

Võtmesõnad: professionaalne areng, algajad õpetajad, kogenud õpetajad, praktiline teadmine, tunnivideo, tunnianalüüs, stimuleeritud meenutus

Haridusteaduste instituut, sotsiaal- ja haridusteaduskond, Tartu Ülikool, Salme 1a, 50103 Tartu,anneokas@ut.ee 


\section{Sissejuhatus}

\section{Suundumustest õpetajauurimustes}

Alates 1960ndatest on pedagoogikaalastes uurimustes keskendutud õpetaja käitumise eri tahkudele ning sellele, kuidas oppetaja käitumine on seotud õpilaste õpitulemustega. Põhiline uurimismeetod on olnud vaatlus klassiruumis. Anderson, Evertson ja Brophy (1979) osutavad, et selliste protsessiväljundi uurimuste (process-outcome studies) eesmärk oli õpetaja tegevuse ja õpilase õpitulemuste vahelise seose väljaselgitamine. 1970ndate lõpul selgus, et ainult õpetaja käitumist uurides pole võimalik saada täit ettekujutust sellest, mis klassiruumis toimub (Meijer, 1999). Enamgi veel, nende uurimuste mõjul ei muutunud õpetamine märkimisväärselt tõhusamaks. Ebaedu põhjusena on viidatud lõhele teadusuuringutes selgitatu ja tegeliku praktika vahel. Paljude arenenud riikide 1970ndatel katsetatud õppekavareformid ja laiema suunitlusega haridusreformid kukkusid läbi, sest need ei arvestanud õpetamissituatsioonide muutlikku iseloomu, millega õpetajad tegelikult kokku puutuvad (Schön, 1983). Samad probleemid ilmnesid Zeichneri ja Gore’i (1990) väitel õpetajakoolituses, kus üliõpilased kurtsid, et loengutes õpetatu ja koolipraktikas kogetu on kaks täiesti erinevat asja.

Alates 1980ndatest hakati õpetajauurimustes enam tähelepanu pöörama õpetaja tunnetustegevusele ja teadmisele ning vähem lähtuma vahetult jälgitavast käitumisest (Meijer, 1999). Clark ja Peterson $(1981,1986)$ nimetasid seda suunamuutust kognitiivseks orientatsiooniks, isegi revolutsiooniks, mis tuli pedagoogikasse psühholoogia valdkonna mõjul ning kujundas õpetaja- ja õpetamisalaste uuringute suundumusi. Mõisteti, et õpetamine on kompleksne tegevus, mis on lahutamatult seotud õpetaja isikupära, tema ainulaadse tunnetuse ja muidugi konkreetse klassisituatsiooniga (Calderhead, 1981; Shulman, 1986). Kuna iga ópetaja praktiline teadmine on oma olemuselt ainulaadne, erinevad õpetajad oluliselt üksteisest. Eriti suured on erinevused algajate õpetajate ja kogenud, üle kümneaastase õpetajatöö kogemusega õpetajate vahel. Kuna õpetamise meisterlikkust pole võimalik saavutada ilma praktilise kogemuseta (Meijer, 2011), siis otsustasid artikli autorid keskenduda oma uurimuses algajate ja kogenud õpetajate praktilise teadmise erinevuste väljaselgitamisele. Käesoleva uurimuse eesmärk on analüüsida algajate ja kogenud õpetajate praktilist teadmist tunnitöö korraldamisel. Otsitakse vastust uurimisküsimusele, millised erinevused ilmnevad algajate ja kogenud õpetajate praktilises teadmises videolindistatud tundide kommenteerimisel stimuleeritud meenutuse meetodil. 


\section{Õpetaja praktiline teadmine}

Õpetaja praktilist teadmist defineeritakse kui professionaalsete teadmiste, oskuste ja hoiakute kombinatsiooni, millel põhinevad õpetajate pedagoogilised otsustused nende igapäevatöös (Krull, 2010; Meijer, 1999; Meijer, Verloop, \& Beijaard, 1999, 2002; Schepens, Aelterman, \& van Keer, 2007). Üks esimesi selle mõiste kasutuselevõtjaid oli Elbaz (1983), kes õpetaja praktilise teadmise sisust rääkides kasutas viit kategooriat:

1) teadmine iseendast (knowledge of self);

2) teadmine õpetamiskeskkonnast (knowledge of the milieu of teaching);

3) ainealane teadmine (knowledge of subject matter);

4) õppekavaarendus (curriculum development);

5) juhendamine (instruction).

Oppetaja praktiline teadmine on uurimisobjekt olnud juba kolmkümmend aastat (Calderhead, 1996; Elbaz, 1983; Fenstermacher, 1994; Meijer, 1999; Meijer et al., 1999, 2002; Shulman, 1986 jt). Praktilise teadmise mõiste kujunemist on tugevalt mõjutanud Schöni (1983) kontseptsioon reflekteerivast praktikust. Selle järgi vaadeldakse õpetaja teadmist kui isikliku refleksiooni väljundit. Shulman (1986) kirjeldas pedagoogilist teadmist samuti personaalsete tunnetusprotsesside avaldumisena. Hulshofi ja Verloopi (2002) järgi on praktiline teadmine seotud kontekstiga, mõnikord varjatud ja alati individuaalse kogemuse refleksioonil põhinev. Fenstermacher (1994) pühendus õpetajate arutluskäikude uurimisele. Tema käsitluse kohaselt on praktiline teadmine see teadmine, mille õpetajad ise loovad, tuginedes oma töökogemusele ning selle refleksioonile. Ühelt poolt on õpetaja pedagoogiliste otsustuste aluseks varasemast töökogemusest ja teooriaõpingutest kujunenud üldistused ning omaksvõetud uskumused ja hoiakud, teisalt mõjutab tehtavaid otsuseid vahetu situatsioon klassiruumis ja interaktsioon õpilastega. Olukorras, kus otsust langetades on võimalik pikemalt järele mõelda, on varasematel teadmistel ja üldistustel suurem roll. Seevastu kiiremat reageerimist nõudvate otsuste puhul on kesksel kohal valmis tegevusmallide rakendamine (Krull, 2010; Schepens et al., 2007). Arutelu õpetaja teadmise üle põhineb sageli teoreetilise (läbitud õpingutest, loetud raamatutest, erinevatelt kursustelt saadud) teadmise ja praktilise (õpetamiskogemusest saadud) teadmise vastuolul (Eraut, 2008). Fenstermacher (1994) ja samuti Meijer (1999) eristavad formaalset teadmist praktilisest teadmisest. Formaalsel teadmisel on uurimuslik alus ja see on n-ö teadmine õpetaja jaoks, samas kui praktiline teadmine on teadmine, mille õpetaja ise on loonud ja mida ta kasutab (Meijer, 1999; Meijer et al., 1999; Schepens et al., 2007). Professionaalid siiski õpivad tööl, seega on õpetaja professionaalse arengu allikas õpetamispraktika (Eraut, 2008). 
Käesoleva artikli autorid on aluseks võtnud ühe rahvusvaheliselt tuntuima lähenemisviisi, mis põhineb Hollandi koolkonna käsitlusel (Meijer, 1999; Meijer et al., 1999; van Driel, Verloop, \& Vos, 1998) õpetaja praktilisest teadmisest. Selle järgi on õpetaja praktiline teadmine jaotatud ühelt poolt teadmisteks ja uskumusteks ning teiselt poolt interaktiivseteks kognitsioonideks, mis jagunevad kümneks kategooriaks (vt tabel 1). Teadmised ja uskumused moodustavad raamistiku, milles õpetaja oma tööpraktikat käsitleb, ning seostuvad pikaajalise mäluga ja funktsioneerivad kui tegevuse üle mõtlemise avaldused. Interaktiivsed kognitsioonid on õpetaja mõtted, mis töö vältel tekivad, ning need seostuvad lühiajalise mäluga ja funktsioneerivad kui tegevuse käigus mõtlemise avaldused (Krull, 2010; Meijer, 1999; Schepens et al., 2007). Õpetaja interaktiivsed kognitsioonid on unikaalsed, sest need on seotud õpetaja konkreetse praktilise tegevusega klassiruumis konkreetsel hetkel (Meijer, 1999).

Tabel 1. Ülevaade õpetajate praktilise teadmise kategooriatest (Meijer, 1999 j)

\begin{tabular}{l|l}
\hline \multicolumn{2}{c}{ PRAKTILINE TEADMINE } \\
\hline $\begin{array}{l}\text { Õpetaja interaktiivsete kognitsioonide } \\
\text { kategooriad }\end{array}$ & \multicolumn{1}{c}{$\begin{array}{c}\text { Õpetajate teadmiste ja uskumuste } \\
\text { kategooriad }\end{array}$} \\
\hline Mõtted konkreetsest klassist & \multicolumn{1}{c}{$*$} \\
\hline Mõtted üksikutest õpilastest & Teadmine õpilastest \\
\hline Mõtted õpilastest üldiselt & Teadmine õpilastest \\
\hline Mõtted õppimisest ja arusaamisest & $\begin{array}{l}\text { Teadmine õpilaste õppimisest ja } \\
\text { arusaamisest }\end{array}$ \\
\hline Mõtted oma ainest & Teadmine oma ainest \\
\hline Mõtted õppekavast & Teadmine õppekavast \\
\hline Mõtted tunni eesmärkidest & Teadmine eesmärkidest \\
\hline Mõtted õpetamismeetoditest & $\begin{array}{l}\text { Teadmine juhendamistehnikatest, meeto- } \\
\text { ditest, õpetamistehnoloogia valdkonnast }\end{array}$ \\
\hline Mõtted õpilaste ja õpetajate vahelisest & \multicolumn{1}{c}{$*$} \\
\hline suhtlusest & $*$ \\
\hline Mõtted õppeprotsessi regulatsioonist & \multicolumn{1}{c}{$*$} \\
\hline
\end{tabular}

Märkus. * - kategooria puudub.

Meijer (1999) nimetab teadmiste ja uskumuste kategooriaid aluskategooriateks (starting categories), mis lähtuvad õppesisu pedagoogilise teadmise (pedagogical content knowledge) kontseptsioonist (van Driel et al., 1998). Esimesena võttis õppesisu pedagoogilise teadmise mõiste kasutusele Shulman (1986). Tema järgi sisaldab see õpetaja arusaamist õpetatavast ainest, ópetamisstrateegiatest ja sellest, kuidas õpilased õpivad. 
Meijer jt (1999) formuleerisid aluskategooriate põhjal kümme interaktiivsete kognitsioonide kategooriat, uurides keeleõpetajate (Hollandi 20 keeleõpetaja) praktilist teadmist. Loodud kategooriad hõlmavad kolme tüüpi praktilist teadmist: I praktilise teadmise tüüp, kus fookuses on aine; II praktilise teadmise tüüp, kus fookuses on õpilane; III praktilise teadmise tüüp, kus fookuses on õpilase õppimine ja õpitu mõistmine. Meijeri (1999) järgi on ainult III praktilise teadmise tüüp täiuslik, kõiki kümmet kategooriat haarav. I ja II tüüpi praktilise teadmise haare on selles tähenduses piiratum.

\section{Õpetaja praktilise teadmise uurimine stimuleeritud meenutuse meetodil}

Kognitiivsest revolutsioonist (Clark \& Peterson, 1986) on ligi kuuskümmend aastat möödas, kuid õpetajate tunnetustegevuse ja teadmise väljaselgitamine on pedagoogikaalastes uurimustes endiselt aktuaalne teema. Mida õpetajad teavad ja usuvad, mis neil mõttes on sel ajal, kui nad õpetavad, pole senini õnnestunud täpselt ja üheselt välja selgitada. Konkreetse teemaga on palju tegelenud Hollandi õpetajakoolituse teadlased, kes on kasutanud oma pedagoogilise psühholoogia uurimustes stimuleeritud meenutusel põhinevaid intervjuusid, dokumenteerimaks ja mõõtmaks õpetajate varjatud pedagoogilist teadmist, mis mõjutab nende hetkeotsustuste tegemist õppetunni ajal (Sugrue \& Day, 2002). Päris esimeseks selle meetodi kasutajaks peetakse Bloomi (1953), kes uuris audiolindistuste abil üliõpilaste mõttearendusi kahes õppesituatsioonis: loengus ja diskussioonis. Stimuleeritud meenutuse meetodit nimetatakse ka introspektiivseks meetodiks, mis sobib õppe-, suhtlemis- ja otsustusprotsesside uurimiseks (Hodgson, 2008). Meetodit kasutatakse iseenesest väga mitmesugustes vormides ja erinevate valdkondade uurimustes: hariduses, spordis, meditsiinis, psühhoteraapias, muusikas. See on professionaalsuse arendamise oluline vahend mitmel elualal (Halter, 2006; Jokinen \& Pelkonen, 1996; Rowe, 2009).

Õpetajate interaktiivsete kognitsioonide uurimine on komplitseeritud ja ajamahukas töö (Meijer, 1999). Käesolevas õpetaja praktilise teadmise uuringus tähendab stimuleeritud meenutuse meetodil uurimine õpetaja antud ja videolindistatud tunni taasesitamist, et ergutada õpetajat meenutama oma mõttetegevust konkreetse tunni ajal. Juba möödunud sajandi 80ndatest peale on kasutatud õpetajate ainetundide lindistamist ja lindistustel põhinevat analüüsi ühe võimalusena õpetaja professionaalse arengu toetamiseks. Laherand (2008) kirjeldab videosalvestiste kasutamist kui head viisi täiustada vaatlusmeetodit, sest need pakuvad vahetu vaatlusega võrreldes suuremat täpsust ning on tehnilises mõttes usaldusväärsemad. Flicki 
(2006) järgi laiendab videosalvestiste kasutamine teiste kvalitatiivsetes uuringutes rakendatavate andmekogumisviiside võimalusi:

1) täiendab helisalvestist ja võimaldab uurida interaktsiooni mitteverbaalset komponenti;

2) annab võimaluse intervjuude mitteverbaalsete tahkude salvestamiseks nende toimumise ajal, selle asemel et kirjeldada neid tagasivaatavalt;

3) rikastab vaatlust, lubades tähelepanuvälja haarata märksa rohkem aspekte ja detaile, kui seda suudaks märkmeid tegev uurija;

4) annab võimaluse kiirelt arenevaid olukordi (nagu näiteks klassiruumis toimuv) üha uuesti üle vaadata.

Videosalvestiste tugevamad küljed avalduvad kombineeritult teiste andmekogumismeetoditega (Laherand, 2008).

\section{Meetod}

\section{Valimi iseloomustus}

20 Eesti põhikooliõpetajat (18 nais- ja 2 meesõpetajat, neist 10 algajat ja 10 kogenud õpetajat) osalesid vabatahtlikult uuringus kahe õppeaasta jooksul (2010/2011 ja 2011/2012). Õpetajad töötasid seitsmes koolis, millest üks oli hariduslike erivajadustega õpilaste kool. Õpetajate töökogemus varieerus: kogenud õpetajad olid koolis töötanud vähemalt 10 aastat, kogenuim neist oli 44aastase tööstaažiga. Algajad õpetajad olid oma karjääri alguses (kuni 3aastase töökogemusega). Uuringus osalenud õpetajad õpetasid põhikooli II ja III astmes erinevaid aineid: eesti keelt emakeelena, inglise keelt võõrkeelena, matemaatikat, keemiat, bioloogiat, geograafiat ja ajalugu.

\section{Mõõtevahendid}

Käesolev uuring on osa mahukamast, õpetaja professionaalset tegevust kajastavast uurimusest, kus algajad ja kogenud õpetajad panid kokku oma professionaalse arengu mapi - portfoolio. Näidisena kasutati van der Schaafi (2005) õpetaja portfoolio mudelit. Õpetaja portfoolio sisaldas järgmisi komponente: enesekirjeldust essee vormis, valikut õpilastele antavatest ülesannetest, kahte intervjuusalvestist (tunnieelne intervjuu ja tunnijärgne intervjuu, mis oli saadud stimuleeritud meenutuse meetodil), ainetunni lindistust, õpetaja reflekteerivat kirjutist oma tugevatest ja nõrkadest külgedest õpetajana ning õpilaste hinnanguid konkreetse aineõpetaja tegevusele lindistatud tunnis. Artikkel kajastab uuringu tulemusi, mis on saadud portfoolio kahe komponendi analüüsist:

1) ainetundide videosalvestistest;

2) oppetajate intervjuudest stimuleeritud meenutuse meetodil. 


\section{Andmekogumine}

Tundide lindistamine. 2010/2011. õppeaastal viidi kahe õpetajaga läbi pilootuuring, mille eesmärk oli hinnata ajakulu ja parandada metoodikat 2011/ 2012. aasta põhiuuringu jaoks. Igalt õpetajalt lindistati üks ainetund. Õpetajate ja õpilaste filmimise ning videosalvestiste kasutamisega kaasnes mitmeid õiguslikke ja eetilisi küsimusi. Kõikide uuringust osavõtvate klassikomplektide õpilaste vanematelt küsiti e-kooli kaudu selleks luba ning seejärel anti teada, mis päeval ja tunni ajal óppetegevust videolindistatakse ning mis on uuringu eesmärk. Lapsevanematel oli võimalik kontakteeruda uuringu läbiviijaga (käesoleva artikli esimene autor) telefonitsi või e-posti teel. Ükski 314 õpilase vanematest uurijaga ühendust ei võtnud. Artiklis toodud näidetes on õpilaste nimed muudetud.

Stimuleeritud meenutusel põhineva intervjuu läbiviimine. Peale lindistatud tundi toimus intervjuu õpetajaga stimuleeritud meenutuse meetodil. Alati ei olnud võimalik täpselt järgida Meijeri (1999) metoodikat, mille kohaselt oleks pidanud intervjuu toimuma vahetult peale tunni salvestamist. Kui kohe polnud võimalik intervjuud läbi viia, näiteks õpetaja pidi minema järgmisse tundi, siis tehti seda esimesel võimalusel. Intervjuule eelnes lühike vestlus, mille jooksul paluti õpetajal kirjeldada enda tundeid ja õpilaste reageeringut tunni ajal. Enne lindistuse vaatamist tutvustati õpetajale stimuleeritud meenutuse meetodi olemust ning julgustati teda igakülgselt avaldama oma mõtteid konkreetse tunni kohta. Kui võis kindel olla, et õpetaja mõistis protseduuri olemust, siis alustati tunnivideo vaatamist. Protseduuri käigus seisati video niipea, kui õpetaja hakkas kommenteerima tunnis toimunut. Kui tekkis pikemaajaline paus, siis katkestas uurija video vaatamise ning palus, et õpetaja räägiks sellest, mida ta tunnis sel hetkel mõtles. Kui õpetaja väitis, et „ta ei mõelnudki eriti midagi” või „ta lihtsalt andis tundi”, siis palus uurija selgitada, mida ta parasjagu silmas pidas või mis tal mõttes oli (nt kui ta andis õpilaste grupile sellise töö). Nii kogu stimuleeritud meenutuse osa kui ka sellele eelnenud ja järgnenud küsimustele vastamine lindistati ja transkribeeriti.

\section{Andmetöötlus}

Õpetajate audiosalvestatud kommentaarid transkribeeriti ja seejärel grupeeriti, kasutades õpetaja interaktiivsete kognitsioonide kategooriaid (Meijer et al., 1999). Grupeerimisel lähtuti Meijeri kategooriatest, sest need võimaldavad hästi süstematiseerida õpetajate mõtteavaldusi. Hollandlaste keeleõpetajate uuringus kasutatud mudel on vajaliku üldistusastmega, seetõttu sobiv erinevate ainete õpetajate praktilise teadmise uurimiseks. Aluskategooriad õpetaja 
teadmiste ja uskumuste kohta on võetud van Drieli jt (1998) tööst, kus neid kasutati loodusainete õpetajate õppesisu pedagoogilise teadmise (ÕPT) uurimisel. Kogutud kommentaarid kategoriseeriti, kaasates usaldusväärsuse suurendamiseks kaks pikaajalise õpetamiskogemusega eksperti: üks humanitaarainete ja teine loodusainete valdkonnast. Et vältida subjektiivsust, valiti eksperdid koolidest, mille õpetajad ei osalenud konkreetses uuringus. Eksperdid töötasid teineteisest sõltumatult. Kahe eksperdi kategoriseerimise kooskõla kommentaaride grupeerimisel määrati Coheni kappa koefitsiendi abil, mis käesoleval juhul oli 0,61.

\section{Tulemused}

Analüüs näitas, et õpetajate kommentaarides olid esindatud kõik kümme interaktiivse kognitsiooni kategooriat. Arvuliselt kõige enam mõtteavaldusi (kokku 86) esitati õpilaste õppimise ja õpitu mõistmise kohta (vt joonis 1). Nimetatud kommentaaridest ligi 2/3 oli kogenud õpetajatelt. Kõige vähem kommenteeriti õppekavaga seonduvat (17), seejuures tuli sellekohaseid kommentaare enam algajatelt õpetajatelt. Kõikide teiste kategooriate puhul oli kogenud õpetajatel algajatest enam kommentaare.

Järgnevalt on iga kategooriat detailsemalt kirjeldatud (näidetes: $\mathrm{A}=$ algaja õpetaja, $\mathrm{K}=$ kogenud õpetaja).

\section{Mõtted konkreetsest klassist}

Kui õpetaja avaldas mõtteid konkreetse klassi kohta, siis enamasti seostusid need klassi tausta või muude karakteristikutega.

Ma olin täitsa üllatunud, muidu on nad mul rahutumad. (A)

Kahjuks pole minu soovitust, et moodustaksime paralleelklassid homogeensetena, kuulda võetud. (K)

Selles klassis peaks kolmandikule koostama individuaalse õppekava, sest teistega võrdselt nad minu ainet omandada ei suuda. (K)

\section{Mõtted üksikutest õpilastest}

Üksikute õpilastega seotud mõtted võib jagada kahte suurde rühma: kommentaarideks, kus õpetaja selgitab õpilase sotsiaalset tausta või muid iseloomulikke jooni, ning kommentaarideks, mis puudutavad konkreetse õpilase õppimist või käitumist. Selle kategooria alla kuuluvates lausungites õpetaja nimetabki ühte või kahte õpilast nimeliselt. 


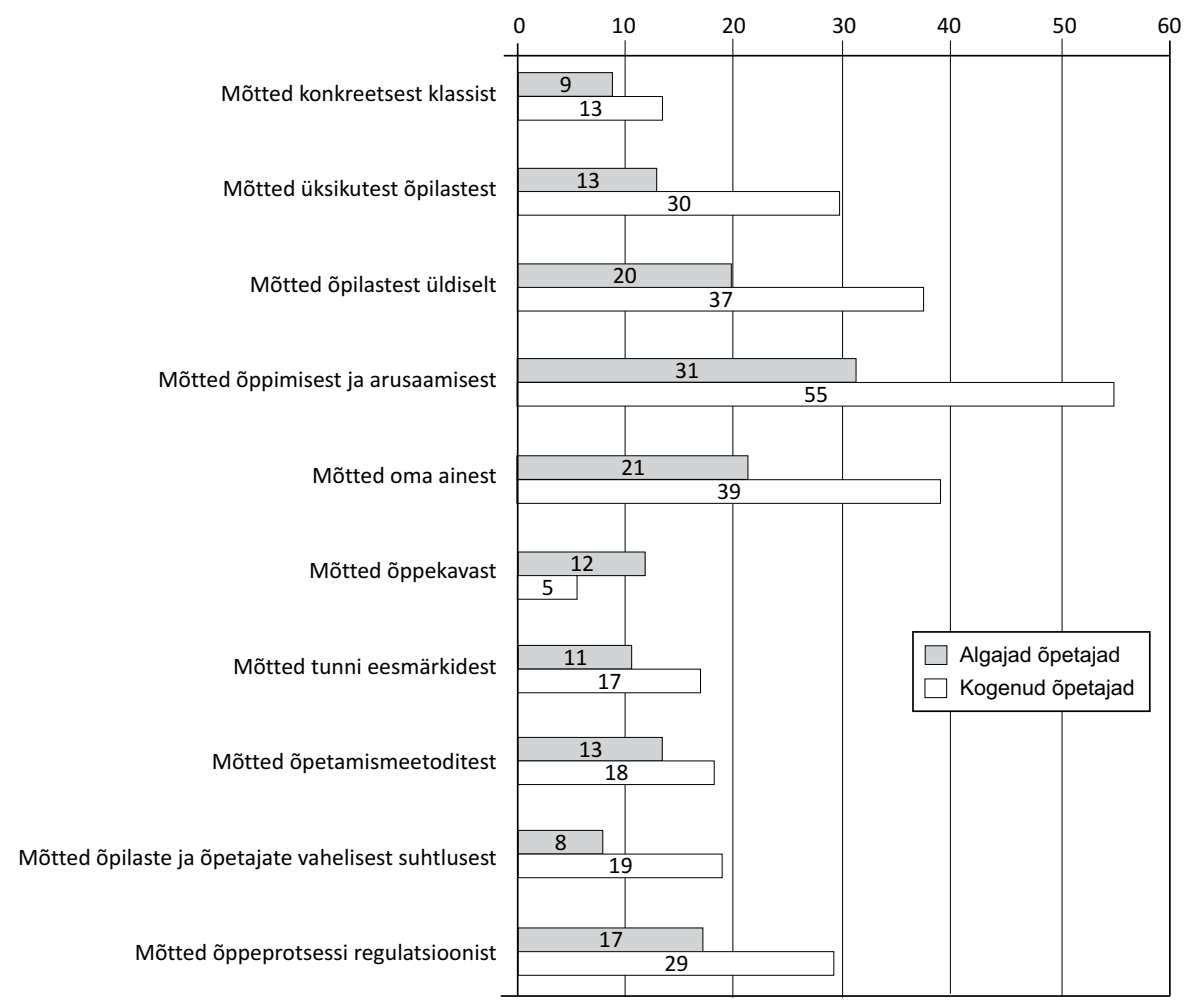

Joonis 1. Uurimuses osalenud algajate ja kogenud õpetajate mõtteavaldused grupeerituna kümnesse õpetajate interaktiivsete kognitsioonide kategooriasse

Mart üllatas täna sellega, et tal oli kodune töö tehtud. Ma mõtlesin, et kas ta ikka ise tegi selle. Tal on väga keeruline kodune olukord. (A)

Gregor tahab igas tunnis tähelepanu endale tõmmata. (A)

Priit täna puudus ja mul polnud põhjust tööd individualiseerida. Tavaliselt ma annan talle keerulisemaid lisaülesandeid, sest ta läheb olümpiaadile. (K)

Tuuli on haiguse tõttu pikemalt puudunud. Muidu on ta oivik, aga just nende puudumiste tõttu oli ta täna tunnis nõrgem. (K)

\section{Mõtted õpilastest üldiselt}

Üldisemat laadi mõtteavaldused kajastasid õpilaste motivatsiooni küsimusi ning iseloomustasid õpilaste iseärasusi, sealhulgas laste ealisi iseärasusi ja nendega seonduvat. Nii algajad kui ka kogenud õpetajad on osutanud, et selles vanuses lastega on kogu aeg probleemid, õppida ei taheta. Nii näiteks on 
öeldud: „See sotsiaalvõrgustikes blogimine on väga tugevalt õpilaste keelekasutust mõjutanud, kasutatakse lühendeid" (K).

\section{Mõtted óppimisest ja arusaamisest}

Kõige enam kommenteerisid algajad ja kogenud õpetajad (vastavalt 31 ja 55 kommentaari) oma tunnilindistusi vaadates õpilaste õppimist ja õpitust arusaamist. Selle kategooria raames esitati mitmeid õpilaste hindamisega seotud kommentaare, anti hinnanguid õpilaste arusaamise kohta ning osutati probleemidele.

Õpilastel on koduste tööde tegemisega probleeme. (A, K)

Nende idiomaatiliste väljenditega seoses - need tuleb lihtsalt selgeks õppida, selle taha jääbki kogu asi. (K)

Mõned on üldse helged pead ja nad võiks ka ise materjali läbi töötada ja saaksid selgeks. Algoritmid kätte. Ja vaat siis on need 4-5 tükki, et tee mis tahad: tee puust ette ja värvi punaseks - nad ikka ei saa aru. (K)

Ma püüan alati tunnis nendega võimalikult palju ära teha, täna me jõudsime vähem, me takerdusime selle ülesande taha. (A)

Olen püüdnud järk-järgult tõsta lahendatavate ülesannete mahtu. Ja seda diferentseerida. (K)

Selliste ülesannetega olen ma ikka püüdnud arendada nende suulist eneseväljendusoskust. (K)

Minu meelest on selle osa läbimisel oluline, et meil oleks aega lahendada võimalikult eritüübilisi ülesandeid, mille läbi võib loota mõtestatud seoste teket. (K)

Kommentaaride kõrvutamisel ilmnes, et nii kogenud kui ka algajad õpetajad pöörasid tähelepanu õpilaste õppimisraskustele, seejuures sisaldasid kogenud õpetajate kommentaarid ka mõtteid nende endi pingutustest probleemide ületamisel. Kogenud õpetajad keskendusid enam õppija arendamisele. Algajate kommentaarid olid pigem sedastavad ja nende mõtteavaldustes domineerisid konkreetse aine õppimisega seotud üksikprobleemid.

\section{Mõtted oma ainest}

Nii kogenud kui ka algajad õpetajad avaldasid arvukalt ainega seotud mõtteid, mis haarasid enamasti järgmisi aspekte: aine raskusaste, aine huvitavus, aine õpetamisega seonduv. 
Olen püüdnud kasutada ka loovtööde koostamist. (A)

Teema on õpikus esitatuna õpilastele pisut raske mõista, nii et mina esitasin seda veidi lihtsamalt, arusaadavamalt. (K)

Ajalugu on ju selline aine, mis ühele osale õpilastest on väga huvitav, nad loevad ja uurivad ise juurde. Kui ma noor olin, käisin õpilastega pidevalt muuseumides, õppekäikudel. Praegu näen, et neil lugemishuvi nagu ei ole. Kõik surfavad internetis. (K)

Üks aspekt, milles algajate ja kogenud õpetajate mõtteavaldused erinesid, oli algajate põhjendamatu taotlus, et õpilased jätaksid õpitava täies ulatuses meelde, nt „Selle teema õppimisel on õpilastel vaja meelde jätta sündmuste ajaline järgnevus". Ka kogenud õpetajad väärtustasid oma kommentaarides õpitava teabe meeldejätmist, kuid pidasid siiski olulisemaks, et õpilased õpitavast aru saaksid ja siis selle meelde jätaksid, nt ,... ülesanne võimaldab seostada õpilastel sellel ajavahemikul toimunud sündmused ja toimumisaja”.

\section{Mõtted óppekavast}

Algajad õpetajad, kes kommenteerisid kogenud kolleegidest enam õppekavaga seostuvat (12 kommentaari kogenud õpetajate $5 \mathrm{vastu}$ ), tõid esile kolm asjaolu: oma ainekava lõimituse teiste ainekavadega, õppekava suure mahu ja probleemid tunnijaotusega ainekava läbimisel. Nii näiteks kommenteeriti: „Mulle oleks vaja kolme tundi nädalas ühe asemel, et kogu seda materjali läbi võtta" (A).

Nii kogenud kui ka algajate õpetajate kommentaarides domineeris teatud kriitilisus õppekava/ainekava suhtes: kriitika puudutas eelkõige mahtu, aga ka seal sisalduvate osade/teemade tähendust ja väärtust, nt „Igal aastal läheb aina hullemaks. Uued õppekavad on võrreldes varasematega probleemsemad. Varasemates oli suurem selgus, just mis puudutab minu ainet" (K).

\section{Mõtted tunni eesmärkidest}

Eesmärke puudutavaid avaldusi oli kokku 28. Kuivõrd tunnieelsel intervjuul keskenduti eesmärkidele, siis asuti ka pärast tundi eesmärkidega seonduvat kommenteerima. Enamasti sisaldasid õpetajate kommentaarid üldsõnalisi hinnanguid tunni eesmärkide saavutamise kohta, nt „Me võtsime tänaseks planeeritu kenasti läbi” (A).

Algajad ei väljendanud oma kommentaarides sellist paindlikkust õpetamisel nagu nende kogenud kolleegid, kes reageerivad kiiresti tunnis toimuvale ja suudavad vajaduse korral oma algset tegevusplaani muuta: „Tunni esimene pool läks mul nii, nagu planeerisin, aga siis ma muutsin ja teises osas ma uue osa tutvustamisest loobusin, sest uue osa juurde minekuks vajasid nad rohkem aega" (K). 


\section{Mõtted ópetamismeetoditest}

Selle kategooria raames kommenteeriti kasutatud õpetamismeetodeid, nt „Kasutasin loenguvormi, sest nii saan neile kõige rohkem materjali edastada” (K). Kommentaare anti ka erinevate tehnikate kohta: „Ma poleks kohe ise selle peale tulnud, aga rääkisin ühe kolleegiga ja tema soovitas mul nii teha" (A), „Seda võtet ma kasutan, et stimuleerida õpilaste loogilist mõtlemist” (K). Leidus ka osutusi teatud töövõtete väljajätmisele ja uute sissetoomisele, nt „... skeem, mida kasutasin, polnud algselt mõeldud selleks tunniks” (K).

\section{Mõtted õpilaste ja õpetajate vahelisest suhtlusest}

Õpetajad mõtlevad õpilaste ja õpetajate suhetele mitmest aspektist. Mõnikord analüüsiti enda suhtlusstiili, nt „Ma ise olen väga kiire inimene, ma nägin küll, et nad ei jõua järele, ma räägin nendega liiga kiiresti” (A), „Mul üldiselt ei ole probleeme ja ma saan oma õpilastega üldiselt hästi läbi” (K).

Kõige suurem mure algajatel oli toimetulek distsipliiniga. Mitmed mõtteavaldused seondusid enesekehtestamisega probleemsituatsioonides.

Mul on vahel probleeme tunni alustamisega, kui vahetunnist tullakse tülitsetuna ja nad ei taha mind siis kuulata. (A)

Ma õpetan seda klassi esimest aastat, pool aastat on juba möödas, aga mul ei ole ikka veel tunnis distsipliini. (A)

Pean väga oluliseks tunni alustamist nii, et kõik õpilased saaksid tööle rakendatud. (K)

Kui kõrvutada algajate ja kogenud õpetajate kommentaare tunni töökorra või distsipliini kohta, siis nähtub selgelt, et kogenud õpetajad lähenevad tunni töökorra tagamisele süsteemselt, leides, et töökorra tagamiseks peaks õpetaja olema selle läbi mõelnud juba tunni algusest peale.

\section{Mõtted õppeprotsessi regulatsioonist}

Protsessi regulatsiooniga, seega paljuski ajakasutuse ja ajastamisega seotud mõtteid esines rohkem algajatel õpetajatel, nt „Ma mõtlesin, et mul oli nendega kogu plaanitud materjal kümme minutit enne tunni lõppu läbi võetud, ja siis mõtlesin, et mis nüüd saab, aga siis tegin veel ..." (A). Mõtteid kogenud õpetajatelt:

Tahaksin tunnis nendega rohkem ülesandeid lahendada, aga õpilaste jõudlus on erinev. Need, kellel on vaja rohkem aega, pidurdavad ka võimekate tööd. (K)

Olen juba mitmel aastal tellinud, et mulle ühel päeval nädalas planeeritaks kaks järjestikust tundi. See võimaldab paremini aega kasutada ja me jõuame süvendatult ülesandeid lahendada. (K) 
Kogenud õpetajad peavad oluliseks, et võimalikult suurt osa tunni ajast saaks kasutada ülesannete lahendamiseks, sest just seeläbi mõtestab ja omandab õpilane õpitut. Nii artiklis näidetena toodud õpetajate lausungites/mõttearendustes kui ka teistes seda tüüpi ütlustes väljendus kogenud õpetajate läbimõeldum ja terviklikum lähenemine tunni sündmustele.

\section{Kommentaaride kokkuvõtteks}

Õpetajate interaktiivsed kognitsioonid hõlmavad kolme tüüpi praktilist teadmist - õppematerjalikeskset, õpilaskeskset ning õppimise ja õpitu mõistmise keskset teadmist -, mida võis ka õpetajate kommentaaride põhjal eristada. Uuringus osalenud algajate õpetajate praktiline teadmine väljendus enam õpetatavale ainele keskendatuses (kommentaarid liigituvad peamiselt I ja II tüüpi praktilise kogemuse alla) ning kogenud õpetajate praktiline teadmine enam õpilase õppimises ja õppimise kaudu arendamises (III tüüp). Kogenud õpetajad ei andnud mitte ainult arvuliselt rohkem kommentaare, vaid nende mõtteavaldused olid ka sisukamad ja tähenduslikumad.

Peale mõtete, mis mahtusid kasutatud kategooriate alla, esitasid tunni vaatamise käigus mitmed õpetajad mõtteid, mis lähtusid nende endi sotsiaalsest seisundist, erinevatest olmelistest asjaoludest ning ka töökorraldusest koolis. Kuna uuringu läbiviimise aega jäi sisuliselt esimene Eesti õpetajate streik (märtsis 2012), siis olid ka õpetajate mõtted mõjutatud sotsiaalsetest pingetest. Nii näiteks avaldati rahulolematust viimastel aastatel märgatavalt suurenenud õpetaja töökoormuse üle. Mitmel korral osutati hariduslike erivajadustega õpilaste õpetamise kohustusele tavakoolis, kus puuduvad selliseks kaasavaks õppeks vajalikud tingimused. Tõsist mõtteainet pakkus Eesti õpetajale tunni filmimine, sest sellega ei olda harjutud. Näiteks kommenteeriti: „Püüdsin küll tundi anda, aga sageli läks mõte filmimisele ja see tekitas minus natuke ärevust.”

\section{Arutelu}

Videolindistuste analüüsimist kasutatakse mitmel elualal professionaalset arengut toetava vahendina. Usaldusväärset informatsiooni õpetaja professionaalse tegevuse kohta võib saada ainult seda tegevust klassiruumis vaadeldes või tundide videolindistusi hinnates (Berliner, 2004). Käesolevas uurimuses selgitati välja olulised erinevused algajate ja kogenud õpetajate praktilises teadmises videolindistatud tundide kommenteerimisel stimuleeritud meenutuse meetodil. Tulemused näitavad, et need erinevused avalduvad nii kvantitatiivselt (kommentaaride rohkuses) kui ka kvalitatiivselt (kommentaaride sisulise erinevusena). Analüüs kinnitab varasematest uurimustest selgunut: kogenud 
õpetajad kommenteerivad tunnisündmusi enam kui algajad. Sato, Akita ja Iwakawa (1993) uurimusest Jaapani õpetajate kohta tuli see selgelt esile. Eesti õpetajate uurimustes on leitud, et algajad on üldiselt napisõnalisemad (Krull, Oras, \& Sisask, 2007). Poom-Valickise (2008) uurimusest ilmneb, et algajate õpetajate reflekteerimisoskus on suhteliselt väike. Ka joonis 1 näitab, et kogenud õpetajad esitasid kokku 262 kommentaari, algajad 155. Seejuures oli vaid üks interaktiivsete kognitsioonide kategooria (mõtted õppekavast), kus algajatelt tuli rohkem kommentaare kui kogenud õpetajatelt.

Teine aspekt on kommentaaride sisuline külg. Algajate õpetajate kommentaarid jäid sagedamini üldsõnaliseks, samas kui kogenud õpetajad suutsid sõnaselgelt välja tuua õpetaja jaoks ühes või teises situatsioonis olulise. Algajad keskendusid enda või mõne teise õpetaja antud õppetundi kommenteerides tihti kitsalt isiklikele küsimustele ja õpetatavale ainele (Krull et al., 2007; Sato et al., 1993). Käesolevas uuringus osalenud algajatel õpetajatel olid isiklikeks probleemideks ajastamine (näiteks oli 10 minutit enne tunni lõppu algaja õpetaja õpilastega selleks tunniks planeeritud tegevused lõpetanud) ning distsipliiniküsimused („,... mul ei ole ikka veel tunnis distsipliini”, „Täna nad üllatasid mind, olid suhteliselt rahulikud").

Erinevalt kogenud kolleegidest keskendusid algajad õpetajad enam oma ainele ja õpilasele ning just üksikutele probleemidele, mitte niivõrd õpilaste õppima suunamisele. Need erinevused ilmnesid eriti ópilastega seotud interaktiivsete kognitsioonide kategooriates (mõtted üksikutest õpilastest; mõtted õpilastest üldiselt; mõtted õppimisest ja arusaamisest; mõtted konkreetsest klassist). Sato jt (1993) täpsustavad, et kui algajad nägid õppetundi kommenteerides vaid üht aspekti - õpetaja või õpilase oma -, siis kogenud õpetajad suutsid õpetamistegevust jälgida mitmest aspektist ja kompleksselt. PoomValickise (2008) uurimusest selgub, et nooremõpetajatel jääb vajaka oskustest kasutada isiklikke kogemusi, mis võimaldaksid neil õppida oma igapäevatööst, ning nende reflekteerimine on pigem kirjeldavat laadi.

Uuringus osalenud algajate õpetajate kommentaaride analüüsil täheldati mõnel juhul vastuolu tunnis tegelikult toimunu ja õpetaja kommentaaride vahel. Näiteks ütles õpetaja, et „siin mul kõik õnnestus”, aga videost nähtus, et kommentaar pole asjakohane. Ühel juhul esitas õpetaja õpilaste motiveerimise asemel neile pigem valmis teavet, mille nad pidid pähe õppima. Teisel juhul andis algaja õpetaja õpilastele enda arvates õige lahendi, kuid õpilasteni lahenduskäik ei jõudnud. Videolindistust kommenteerides käsitlesid õpetajad neid situatsioone kui õnnestumisi.

Uuringust selgus, et algajad õpetajad keskendusid õpetamisel enam õpetatavale ainele ja aineteabe meeldejätmisele. Ka kogenud õpetajad väärtustasid oma kommentaarides aineteabe meeldejätmist, kuid pidasid kõige 
olulisemaks, et õpilased saaksid aru, mida nad peavad meelde jätma. Nende mõttearendustes võis lõppeesmärgina näha aineosa/teema mõtestatud omandamist. Analüüsides kogenud õpetajate kommentaare, ei jää märkamatuks nende orienteeritus õpilastele, kellele see tund on mõeldud (mida ta õpetajana tahtis, st mis oli eesmärk, ning mida ta tegi, et seda eesmärki õpilastega saavutada). Praktilise teadmise tüpoloogia kohaselt olid algajate õpetajate tähelepanu keskmes eelkõige õpetatav aine ja õpilane (Meijeri järgi I ja II tüüpi praktiline teadmine), kogenud õpetajad keskendusid enam õpilase õppimisele ja õpitust arusaamisele (III tüüpi praktiline teadmine). Sato jt (1993) tõid oma uurimuses välja, et suurte kogemustega õpetajad on aktiivsed probleemilahendajad. Ka käesolevas uurimuses leidis kinnitust, et kogenud õpetajad reageerivad kiiremini tunnis toimuvale ja suudavad probleemide ilmnemisel oma planeeritud tegevust muuta. Algajatel sellist paindlikkust polnud.

Varasematest õpetaja praktilise teadmise uurimustest (Meijer et al., 1999) on selgunud, et tervikliku praktilise teadmise kujunemine võtab õpetajal aega. Meijeri III tüübile vastava ja kõikides interaktiivsete kognitsioonide kategooriates avalduva praktilise teadmise kujunemine nõuab pikaajalist õpetajatöö kogemust. Ilma selleta ei ole võimalik saavutada õpetamises ka meisterlikkust. Kogenud õpetajad on tänu oma pikaajalisele kogemusele saanud suure teadmiste pagasi ja arendanud selle põhjal välja oma praktilise teadmise (Carter, 1990; Meijer, Zanting, \& Verloop, 2002). Noor õpetaja saab oma karjääri alguses toetuda ülikoolis ópitule ja oma kooliajast kogetule. Siiski, teooria ja praktika seostamine pole lihtne. Sageli tuleb välja, et need kaks on sootuks erinevad (Meijer, Zantig, \& Verloop, 2002). Leshem (2008) osutab, et algajad ei suuda õpetajakoolituses saadud pedagoogikateadmisi sageli ühendada reaalsete õpetamissituatsioonidega.

Arvestades varasemaid uurimusi, jagavad artikli autorid seisukohta, et baaskoolitusel on oluline osa õpetaja professionaalsuse kujunemisel ja sellele tuleks veelgi sügavam tähendus anda. Meie uurimus kinnitab, et tunnivaatlused ja videolindistused aitavad saada ettekujutuse klassi töökorraldusest, samuti sellest, milline seos on õpetaja juhendamisel ja õpilaste tegevusel - õppimisel. Et õpetajana paremini analüüsida enda või teiste antud tunde, on otstarbekas kasutada tundide videolindistusi ning vaadelda tunde etappide kaupa. Töö aluseks oleva kvalitatiivse uurimismetoodika rakendamisel osutusid kõige raskemaks läbirääkimised õpetajatega, veenmaks neid uuringus osalema. Õppetunni filmimine on Eesti koolides vähe levinud praktika ning paljud õpetajad olid selle suhtes väga skeptilised.

Käesoleval uuringul on mitmed piirangud. Esiteks, valimi väiksus, mille tõttu pole tulemusi võimalik üldistada. Lisaks osalesid õpetajad uuringus vabatahtlikkuse alusel, mis sundis piirduma vaid ühe tunniga iga õpetaja 
kohta. Ei saa välistada, et mõne teise valimi puhul võivad tulemused olla teistlaadsed. Õpetaja praktiline teadmine on siiski unikaalne. Ehkki valiidsust ei saa selle konkreetse meetodi, nagu ka paljude teiste kvalitatiivsete käsitluste puhul täielikult kontrollida, pakub see tehnika - stimuleeritud meenutuse meetod - siiski süsteemset lähenemist õpetaja praktilise teadmise uurimisele.

\section{Kokkuvõte}

Stimuleeritud meenutuse meetodi rakendamine tunnianalüüsiks on kasulik nii algajatele kui ka kogenud õpetajatele, kes soovivad oma kutseoskusi täiendada. Oma antud tunni vaatlustulemusi saab analüüsida, hinnates tunnis toimuvat mitmest aspektist, näiteks võib lahata tunni eesmärgi ja tulemuse seost, püstitatud eesmärgi sobivust õpilaskontingendiga, samuti õpetaja ja õpilaste suhtlust. Käesolevas uurimuses analüüsisime, milline praktiline teadmine eristub algajate ja kogenud õpetajate kommentaarides tundide videolindistusi vaadates. Kõrvutades algajate ja kogenud õpetajate kommentaare, ilmnes, et mõlemad õpetajate rühmad väärtustavad õpilase jaoks õppimisprotsessi lópptulemust - õpitava omandamist. Kommentaaride põhjal seisneb algajate ja kogenud õpetajate põhierinevus selles, et algajad keskenduvad enam lõpptulemusele, samas kui kogenud õpetajad mõistavad lõpptulemusele jõudmise astmelist keerukust.

Eesti õpetajakoolituses ja õpetajate täiendusõppes tasub kindlasti senisest rohkem kasutada tundide videosalvestisi. Õpetajakoolituse kursuste maht on limiteeritud, seetõttu tasub mõelda, kuidas olemasolevat aega üliõpilase jaoks sisukamaks muuta. Koolituse sisulist poolt aitaks viia paremuse poole see, kui õpetajakoolituse üliõpilased vaatleksid nii algajate, sealhulgas iseenda praktika ajal antud tunde kui ka kogenud ópetajate tunde. Just óppetunni lindistuse ülevaatamine ja seega tunnis toimunu meenutamine võimaldavad õpetajal süvendatud eneseanalüüsi vormis keskenduda oma tegevusele.

\section{Tänuavaldus}

Suurim tänu kuulub uuringus osalenud õpetajatele. Suur tänu Utrechti ülikooli professorile Paulien Meijerile konsultatsioonide eest. Artikli valmimist toetas Euroopa Sotsiaalfondi EDUKO projekt „Õpetajate professionaalne areng ja selle toetamine" (1.2.0302.09-004) ning haridus- ja kasvatusteaduste doktorikool (1.2.0401.09-0070). 


\section{Kasutatud kirjandus}

Anderson, L., Evertson, C., \& Brophy, J. (1979). An experimental study of effective teaching in first-grade reading groups. Elementary School Journal, 79(4), 193-223. http://dx.doi.org/10.1086/461151

Berliner, D. C. (2004). Expert teachers: Their characteristics, development and accomplishments. Retrived from http://www.sportscoachuk.org/sites/default/files/Berliner\%282004\%29-Expert-Teachers.pdf.

Bloom, B. S. (1953). Thought processes in lectures and discussions. Journal of General Education, 7, 160-169.

Calderhead, J. (1981). Stimulated recall: A method for research on teaching. British Journal of Educational Psychology, 51(2), 211-217. http://dx.doi.org/10.1111/j.2044-8279.1981.tb02474.x

Calderhead, J. (1996). Teachers: Beliefs and knowledge. In D. C. Berliner \& R. C. Calfee (Eds.), Handbook of educational psychology (pp. 709-725). New York: Macmillan.

Carter, K. (1990). Teachers' knowledge and learning to teach. In W. R. Houston, M. Haberman \& J. P. Silkula, Handbook of research on teacher education (pp. 291310). New York: Macmillan.

Clark, C. M., \& Peterson, P. L. (1981). Stimulated recall. In B. R. Joyce, C. C. Brown \& L. Peck (Eds.), Flexibility in teaching: An excursion into the nature of teaching and training (pp. 256-261). New York: Longman.

Clark, C. M., \& Peterson, P. L. (1986). Teachers' thought processes. In M. C. Wittrock (Ed.), Handbook of research on teaching (3rd ed.) (pp. 291-310). New York: Macmillan.

Elbaz, F. (1983). Teacher thinking: A study of practical knowledge. New York: Nichols Publishing Company.

Eraut, M. (2008). Developing professional knowledge and competence. New York: Routledge Falmer, Taylor \& Francis Group.

Fenstermacher, G. D. (1994). The knower and known: The nature of knowledge in research on teaching. Review of Research on Teaching, 20, 3-56.

Flick, U. (2006). An introduction to qualitative research (3rd ed.). London: Sage Publications.

Halter, C. P. (2006). The reflective lens: The effects of video analysis on preservice teacher development. (Doctoral dissertation). University of California, San Diego.

Hodgson, V. (2008). Stimulated recall. In R. Thorpe \& R. Holt (Eds.), The SAGE dictionary of qualitative management research. Retrived from http://srmo.sagepub.com/ view/the-sage-dictionary-of-qualitative-management-research/n2.xml.

Hulshof, H., \& Verloop, N. (2002). The use of analogies in language teaching: Representing the content of teachers' practical knowledge. Journal of Curriculum Studies, 34(1), 77-90. http://dx.doi.org/10.1080/00220270110037177

Jokinen, P., \& Pelkonen, M. (1996). Virikkeitä antava haastattelu - menetelmä käsitysten, kokemusten ja ajattelun tutkimiseen hoitotieteessä. Hoitotiede, 8(3), 134-141.

Krull, E. (2010). Õpetajakoolituse praktika optimeerimise võimalusi toetudes Eesti, Hollandi ja Soome kogemustele. V-R. Ruus \& E-S. Sarv (koost.), Õpetaja esmaharidus. Olukord ja probleemid 21. sajandi algul (lk 101-120). Tallinn: Tallinna Ülikool.

Krull, E., Oras, K., \& Sisask, S. (2007). Differences in teachers' comments on classroom events as indicators of their professional development. Teaching and Teacher Education, 23(7), 1038-1050. http://dx.doi.org/10.1016/j.tate.2006.02.001 
Laherand, M-L. (2008). Kvalitatiivne uurimisviis. Tallinn: OÜ Infotrükk.

Leshem, S. (2008). Novices and veterans journeying into real world teaching: How a veteran learns from novices. Teaching and Teacher Education, 24(1), 204-215. http://dx.doi.org/10.1016/j.tate.2006.07.010

Meijer, P. C. (1999). Teachers' practical knowledge. Teaching reading comprehension in secondary education. (Doctoral dissertation). Leiden University, Leiden.

Meijer, P. C. (2011). Teachers' practical knowledge as part of teacher education. Lecture in University of Tartu on the $5^{\text {th }}$ of October. Unpublished raw data.

Meijer, P. C., Verloop, N., \& Beijaard, D. (1999). Exploring language teachers' practical knowledge about teaching reading comprehension. Teaching and Teacher Education, 15(1), 59-84. http://dx.doi.org/10.1016/S0742-051X(98)00045-6

Meijer, P. C., Verloop, N., \& Beijaard, D. (2002). Multi-method triangulation in a qualitative study on teachers' practical knowledge: An attempt to increase internal validity. Quality and Quantity, 36(2), 145-167. http://dx.doi.org/10.1023/A:1014984232147

Meijer, P. C., Zanting, A., \& Verloop, N. (2002). How can student teachers' elicit experienced teachers' practical knowledge? Tools, suggestions and significance. Journal of Teacher Education, 53(5), 406-419. http://dx.doi.org/10.1177/002248702237395

Poom-Valickis, K. (2008). Algajate õpetajate professionaalne areng kutseaastal. Analüütiline ülevaade. (Dissertatsioon). Tallinna Ülikool, Tallinn.

Rowe, V. C. (2009). Using video-stimulated recall as a basis for interviews: Some experiences from the field. Music Education Research, 11(4), 425-437.

http://dx.doi.org/10.1080/14613800903390766

Sato, M., Akita, K., \& Iwakawa, N. (1993). Practical thinking styles of teachers: A comparative study of expert and novice thought processes and its implications for rethinking teacher education in Japan. Peabody Journal of Education, 68(4), 100-110. http://dx.doi.org/10.1080/01619569309538745

Schepens, A., Aelterman, A., \& van Keer, H. (2007). Studying learning processes of student teachers with stimulated recall interviews through changes in interactive cognitions. Teaching and Teacher Education, 23(4), 457-472.

http://dx.doi.org/10.1016/j.tate.2006.12.014

Schön, D. A. (1983). The reflective practitioner: How professionals think in action. New York: Basic Books.

Schön, D. A. (1987). Educating the reflective practitioner. San Francisco: Jossey-Bass.

Shulman, L. S. (1986). Those who understand: Knowledge growth in teaching. Educational Researcher, 15(2), 4-14. http://dx.doi.org/10.3102/0013189X015002004

Sugrue, C., \& Day, C. (Eds.) (2002). Developing teachers and teaching practice. London: Routledge/Falmer.

Van der Schaaf, M. F. (2005). Construct validation of teacher portfolio assessment. Procedures for improving teacher competence assessment illustrated by teaching students research skills. (Doctoral dissertation). Utrecht University, Utrecht.

Van Driel, J., Verloop, N., \& Vos, W. de (1998). Developing science teachers' pedagogical content knowledge. Journal of Research in Science Teaching, 35(6), 673-695. http://dx.doi.org/c7d4ct

Zeichner, K. M., \& Gore, J. M. (1990). Teacher socialization. In W. Houston (Ed.), Handbook of research on teacher education (pp. 329-348). New York: Macmillan. 


\title{
Teachers' Practical Knowledge in Novice and Experienced Teachers' Comments on Classroom Interactions
}

\author{
Anne Okas ${ }^{\mathrm{a} 1}$, Marieke van der Schaaf ${ }^{\mathrm{b}}$, Edgar Krull ${ }^{\mathrm{a}}$ \\ ${ }^{\text {a }}$ University of Tartu, Institute of Education \\ ${ }^{\mathrm{b}}$ Utrecht University, Department of Education
}

SUMMARY

In the 1960s, research on teaching mostly focused on the behaviour of teachers and on how this behaviour related to outcomes in student learning. From the 1970s, it became clear that the results of studies on teacher behaviour did not lead to a better understanding of what actually goes on in classrooms. In addition, these results did not seem to improve teaching practice. Schön (1983) described this as a gap between the research done and the actions of practitioners. In the following years research on teaching changed direction and increasingly focused on the cognitions that underlie classroom practice rather than on teacher behaviour (Calderhead, 1996; Carter, 1990; Meijer, 1999; Meijer, Verloop, \& Beijaard, 1999; Shulman, 1986). This "cognitive revolution", which came from the field of psychology, influenced pedagogy in several ways: the topics of the studies now focused on teachers' planning, their interactive thoughts and their decision-making. New instruments and procedures were developed, such as narrative techniques and stimulated recall techniques (Meijer, 1999). More than four decades after this cognitive change in research on teaching, teacher knowledge and cognitions are still topical issues.

The concept of a teachers' practical knowledge has been a subject of interest in educational sciences for the last two decades (Calderhead, 1996; Fenstermacher, 1994; Meijer et al., 1999, 2002). Fenstermacher was one of the first scholars to investigate teaching within the framework of the practical reasoning of teachers. He defined personal practical knowledge as the knowledge that teachers themselves generated as a result of their experiences and reflections on these experiences (Fenstermacher, 1994). One of the bestknown conceptualisations of what teachers know is written by Shulman (1986), who pointed out the complex nature of expertise in teaching. Meijer (1999) and Meijer et al. (1999) described teachers' practical knowledge as the cognitions that underlie teacher actions. They considered teachers'

1 Institute of Education, Faculty of Social Sciences and Education, University of Tartu, Salme 1a, 50103 Tartu, Estonia, anneokas@ut.ee 
practical knowledge to consist of knowledge and beliefs on the one hand, and interactive cognitions on the other. Teachers' interactive cognitions is a term used in the context of the teaching situation, and which focuses on the cognitions teachers have while teaching. The knowledge and beliefs of teachers are stored in their long-term memory, and are defined as the frame of reference through which practice is perceived. Interactive cognitions are related to the actual behaviour of teachers and short-term memory - these are the thoughts that occur when teaching (Schepens, Aelterman, \& van Keer, 2007).

The current study is based on material from research carried out in Estonian schools with the cooperation of 20 teachers (18 female and 2 male; ten experienced teachers and ten novice teachers) in the 2010/2011 and 2011/2012 academic years. The study aims to analyse teachers' practical knowledge in comments about classroom interactions by novice and experienced teachers. The concept of teachers' practical knowledge was used as a framework for analysing the video recordings and stimulated recall interviews collected for the study. Research question: How do novice and experienced teachers differ in terms of their practical knowledge in comments on classroom interactions?

We videotaped one lesson by each teacher, and 20 interviews were conducted after the videotaped lessons using the stimulated recall method. The videotape is used to aid a teacher's recall of his or her interactive thoughts at the time of the lesson (Calderhead, 1981). In a stimulated recall method for interviewing, teachers explained their interactive thinking while watching a videotape of a lesson they have just given. We stopped the videotape every time the teachers recalled what they were thinking or what was on their minds and encouraged them to say everything they could remember thinking at the time. All interviewees retained anonymity. The aim (according to Meijer's methodology) was to conduct the stimulated recall interview right after the lesson. Sometimes this was not possible because, for example, the teacher was scheduled to teach other lessons. During the watching, we stopped the tape whenever the teacher started to make comments. An audio-recording was made of the teachers' comments, and this recording was then transcribed.

Based on research by Meijer et al. (1999), we analysed the results in the light of ten interactive cognitions (thoughts about the particular class, individual students, students in general, student learning and understanding, subject matter, curriculum, goals, instructional techniques, teacher student interaction, process regulation) and three types of teachers' practical knowledge (subject matter knowledge, student knowledge and knowledge of student learning and understanding). In this article the content of each 
category of teachers' interactive cognitions is described and illustrated using fragments from the stimulated recall interviews. The teachers' interactive cognitions included all three types of practical knowledge. The results showed that practical knowledge in the comments of experienced teachers is more integrated, viewing teaching as developing student potential (the third type of practical knowledge with a focus on student learning and understanding). The practical knowledge of experienced teachers was more complete, while novice teachers focus systematically on material. Previous studies point to comparative results (Krull, Oras, \& Sisask, 2007; Sato, Akita, \& Iwakawa, 1993; Schepens et al., 2007). Although novice teachers are familiar with teaching theories, they focus on teaching their own subject (the first type of practical knowledge with a focus on subject matter).

This study does not intend to generalise its research findings because it was carried out in a specific context with a relatively small sample of teachers. Besides, the teachers participated in this study on a voluntary basis. Future research not only needs to focus on the use of the stimulated recall interview as a tool to support professional development among teachers, but also on promoting change in teachers' conceptions of reflecting upon and assessing their own work.

\section{Acknowledgements}

Greatest thanks go to the teachers who participated in this study. We thank Professor Paulien Meijer for her consultations. We would also like to express our gratitude to the reviewers for their helpful suggestions. This article was supported by the ESF programme EDUCO No. 1.2.0302.09-004 (ÕPA grant) and ESF project No. 1.2.0401.09-0070 Doctoral School of Educational Sciences.

Keywords: professional development, novice teachers, experienced teachers, practical knowledge, video recording, lesson analysis, stimulated recall 